\title{
An Analysis of Past Indo-Pakistan Nuclear Crises ${ }^{1}$
}

\author{
Prof. Dr. Razia Musarrat \\ Professor and Chairperson, Department of Political Science \\ The Islamia University of Bahawalpur Pakistan \\ Email: drrazia_mussarat@yahoo.com
}

\begin{abstract}
After more than half of a century, Pakistan and India are still trapped in history of events right from 1947 o date. Differences between two nations have been and still based on suspicion and distrust and resultantly charged emotions of both nations have often pushed relations between the two nations far beyond normal limits. Since partition of 1947, military history of both Pakistan and India is comprised of repeated military misadventures. Nuclear development of both countries has added much complexity to the security scenario. This study examines nuclear crises dimension of security relations between two nations. Historic enmity between the relations of both countries demands a serious analysis of past Indo-Pakistan nuclear crises.
\end{abstract}

Keywords: Globalization, Society, policy, Effects of globalization on policy making

${ }^{1}$ Complete study of previously published in-complete work in Al-Siyasa: University of Punjab Lahore 


\section{Introduction}

Nuclear relations between Pakistan and India has been remained a sensitive subject and there is ample evidence from history that verifies the context of sensitivity and complexity. World was caught unaware on May 11, 1998 when the world was reminded that nuclear proliferation was still an issue. Indian nuclear tests on May 11 and 13 at Pokhran triggered a new era in the nuclear relations between Pakistan and India. Keeping in view the continuous military engagement between the Indian and Pakistani armies a new era of nuclear tension began. Form this point onwards, there is a series of events that has led to a military stand-off between the two arch rivals that was nuclear in nature. Two major events, Kargil war 1999 and the military stand-off in 2001-02 are however the two most prominent nuclear crises that were developed. This study is an attempt to analyze the nuclear crises of the past in detail to understand the possible outcomes, military designs and future shape of conflict between the two nations. This however, cannot be achieved without understanding the historic development of nuclear weapons in Pakistan and India and their deployment as well as the nuclear doctrines of both the rivals.

Kashmir, the disputed territory between Pakistan and India is a key bone of contention that has never been seriously considered for resolution through peaceful means by the international community. According to Bill Clinton, Kashmir was 'the most dangerous place in the whole world'. It was in the President Clinton second era that India and Pakistan were engaged in reciprocal tests of nuclear weapons in 1998 that was followed by Kargil war in 1999. Kargil war was the first conflict between the two nuclear weapons states. This proved to be the beginning of a tense nuclear era that saw another serious nuclear crisis soon after the event of 9/11. On 13 December, 2001, terrorist attack on Indian parliament building provoked another serious military crisis. This attack on Indian Parliament led to first full mobilization of the Indian Army since Indo-Pak war of 1971. Mumbai attacks in recent history is another example of sensitive and fragile nuclear relations between India and Pakistan. 2008 Mumbai attacks led to another nuclear crisis that could have easily got out of control. This time it was the dimension of surgical air strikes by the Indian Air Force that caused a stir in the security situation. Pakistan refused to rule out the use of nuclear weapons if surgical strikes were attempted by the Indians. To fight Pakistan on a limited scale has no guarantee what so ever that it will not go nuclear. To explain further the dynamics of nuclear security between India and Pakistan, this study is organized into following sections.

II - INDO-PAK Nuclear Development

III- Kargil 1999

IV- 2001-02 Nuclear Standoff

V-Analysis

VI- Conclusion 


\section{II - INDO-PAK Nuclear Development}

\section{NUCLEAR DEVELOPMENT}

\section{Pokhran-I (The Smiling Buddha):}

First nuclear test conducted by India on 18 May 1974 at Pokhran Test range was of estimated intensity of 8 Kiloton. India became first nuclear capable state outside the five permanent members of United Nations Security Council. This pushed Pakistan towards development of nuclear arms. Pakistan's security was threatened to an extent that its Prime Minister Zulfikar Ali Bhutto announced to build atomic bomb even if it had to be on the cost of the economy of Pakistan.

\section{Cold Tests -1983:}

During the 80 s and early 90 s a series of different cold tests were conducted by Pakistan Atomic Energy Commission and Kahuta research Laboratories (later Abdul Qadeer Khan research laboratories) under extreme. Several sites were built for hot test during this period. Tunnels at Chaghi were also building in the same period by a dedicated team under the command of a in-service Brigadier of Pakistan Army. However, conduct of hot test was not possible because of international focus in the region as USSR (Now Russia) invaded Afghanistan and security scenario in South East Asia changed completely. Russian Invasion invited American involvement in the region and later in the proxy war against Russia that completely changed the scenario in favour of Pakistani clandestine nuclear programme. It is widely reported that though American knew about nuclear development programme of Pakistan, they were not in a position of pressurizing Pakistan to cap it because Pakistan's help was desperately needed by the Americans to fight proxy war with Russia in the region. During this time security interests of US aligned with Pakistan and Pakistan took full advantage of this factor for its nuclear development programme.

\section{Pokhran-II (Operation Shakti)}

India detonated another 5 nuclear devices at Pokhran Test Range on 11 May 1998. This test was conducted in entirely different period than that of 1974. In the context of Indian society, media and government of BJP, it was a matter of national pride. There were concerns but ignored by the Indian government. However, main element for analysis was the reaction from Pakistan. It triggered a security dilemma from Pakistan's point of view. Pokhran-II tests and then statements on Kashmir by BJP government officials pushed Pakistan towards hot nuclear testing. This was not well received by the international community that exerted maximum possible pressure on Pakistan not to conduct the tests. From Pakistan's security point of view, this was the only logical outcome to re-establish balance of power in the region.

\section{Chaghi-I: (Yom-e-takbir)}

Reaction of Pokhran-II nuclear tests came on 28 May 1998 when Pakistan detonated 5 nuclear devices to reciprocate Indian nuclear tests of 11 and 13 May 1998. These tests were celebrated at large by the Pakistani public and like Indian tests, it was a matter of national pride. Pakistan became first and only Muslim nuclear power. This day was titled later as 
"Yom-e-Takbir" and is celebrated every year since 1998 as a day of national pride.

\section{Chaghi-II:}

Pakistan conducted more tests on 30 May 1998 and announced completion of its own series of underground tests. Implications of these tests were however different for Pakistan and India. It had much greater economic and political fall-out for Pakistan than for India. These tests led to create a military mindset that became one of the primary reasons of Kargil war 1999. It was the wrong assumption of controlled conflict by the Pakistani military high command that led to the crisis of Kargil in 1999.

\section{III- Kargil 1999}

One of the main ideas behind Kargil military campaign was believed to interdict Indian supplies from their usual route. Kargil hills are always unoccupied during winters and when Pakistan army captured it, it was untenanted, as India had vacated it due to the harsh snowing season. Pakistani forces took the area without any combat or resistance because there was no Indian forces present in that area.

It is reported in media that Indians were informed of the Pakistani occupation of the Kargil hills few months later through a shepherd who went there. Having said that, initial campaign that included transportation of guns and other ammunition was unprecedented in the history of that region. However, Pakistan was not in a position for the logistics buildup. Quickly after knowing the about the occupation by Pakistan, India mobilized its army and air force and inflicted heavy damage to Pakistan. There is no question about the fact that if the war had continued for another couple of months, Pakistan would have faced more damages, in terms of human, war equipment and political. After realization of factual position in the crisis, Nawaz Sharif government initiated the diplomatic process by involving the then US President Bill Clinton and got Pakistan face saving solution to resolve the crisis.

What is most important is the fact that entire security paradigm changed between the two de facto nuclear weapon states. It is believed that after Kargil, India evolved a doctrine of limited conventional conflict for its nuclear neighbourhood in South Asia. Key factor of this doctrine is the same wrong misperception (the one that had taken by Pakistan Army in Kargill 1999) that there was a possibility of a low-intensity and a high-intensity conventional conflict where a limited conventional war was possible that means a "controlled limited conflict".

One of the immediate and important results of Kargil War in 1999 was that India announced its Draft Nuclear Doctrine. This nuclear doctrine represents a dominant thinking like of a superpower yet it lacked the required depth of ground realities. There are people in Indian security policy thinking those have a specific point of view that a limited war or confrontation with Pakistan can be managed without escalation of conflict into a full war. But this perception is too dangerous and risky on ground. Because there is no guarantee that once conflict slips into war and war expands than nuclear weapons would not be used. Especially in the case where Pakistan has already announced its nuclear doctrine of aggressive nature.

Further, the development and deployment of advance delivery systems and mechanisms such 
as space weapons programme could reduce response as well as decision making time very short. In other words, this means that nuclear environment would be so fragile that there would be practically launch-on-warning approach at the deployment level which is far too risky in the context of a nuclear confrontation. It is very important to keep the distance under consideration. Travel time of delivery systems such as missiles are not more than ten minutes between the two neighbours. That means there is no absolutely no luxury of thinking at that very moment that was once available in the cold war days to US and USSR. Always high-Alert posture of at least one portion of nuclear weapons means high domestic risk of internal sabotage or other un-seen threats. Given to the local security environment, this is a big and risky ask that could easily back fire.

Kashmir as discussed earlier is therefore of key importance in the $21^{\text {st }}$ century for India and Pakistan. It is the issue of Kashmir that has to be resolved or at-least cease fire would have to be kept in place to avoid any escalation of conflict that could lead to any other difficult dimension of war including but not limited to the use of nuclear weapons.

\section{IV- 2001-02 Nuclear Standoff}

Indian leadership had developed a misconception after Kargil war 1999 that a limited battle can be managed with Pakistan without deploying nuclear weapons. This misconception is risky as well as irresponsible because we are not talking about just another type of weaponry, we are talking about nuclear weapons and the lives of the millions of people of the region. After 9/11 US waged war against terrorism. Indian parliament was attacked by terrorists in December 2001 and soon after the attack India mobilized its armed, naval and air forces and deployed along the border of Pakistan in a very aggressive military manner. Same was reciprocated by Pakistan and LoC (Line of Control in Kashmir) once again sensitized by India and Pakistan. India's Home Minister, L. K. Advani, on December 19, 2001, demanded from Pakistan to:

a. Strike against the alleged militant Islamic organisations and groups allegedly involved in attacking Indian Parliament.

b. Cessation of support to cross-border terrorism alongside LoC.

c. Handover of 20 individuals accused of terrorism in India.

As discussed earlier it was Indian leadership's perspective that a major or a limited conventional war against Pakistan was possible without triggering the use of nuclear weapons. They also planned surgical strikes across the LoC into the Pakistani-controlled part of Kashmir on the justification of combating terrorism and to destroy the alleged terrorist camps. However, this reactive Indian design was expected to evoke a Pakistani counter response that could not have guaranteed Non-use of nuclear weapons. Therefore, if Indian strategy would have backfired, it would have disastrous implications for both countries. There was no way to determine the threshold when confrontation would become nuclear. 


\section{V-Analysis}

Starting with basic facts is the realization that nuclear conflict is of passive strategic nature. Pakistan has stated first strike policy for its nuclear doctrine and this also includes a situation where any of its forces, army, navy or air force are unable to defend or control the invasion than use of nuclear weapons could be deployed. Although India has stated no first use policy but considering the stated position of Pakistan, every conflict that can lead to escalation in military engagement between the two countries can be very dangerous. Because Pakistan in its war history has never been able to sustain a war. This means when a point comes like it was in 1971 where a territory was under threat; use of nuclear weapons could make its way.

Scholars of security studies are of the view that incase of Indian seizure of substantial Pakistani territory or Indian destruction of substantial portions of the Pakistan Army or Air Force in conflict in such a way that their existence is threatened that it could be the possible triggers for Pakistan to use nuclear weapons. This means that India should and it must by security complications keep these parameters in mind while planning any military adventure. We should not forget that substantial advantage that India has in terms of its conventional military might. This advantage would play a key role in the decision about use of nuclear arsenal of Pakistan. New international political scenario has central place for terrorism. Terrorism and not Kashmir can also be a primary provocative trigger for a military conflict. A valid and practical example is the recent aftermath of Mumbai terrorist attacks in 2008 where surgical strikes initiative as was proposed by the Indian military establishment could have triggered a military conflict that could have easily been escalated into a nuclear confrontation.

Another dimension to my analysis is the very fact that limited military campaigns and especially in the context of India and Pakistan would produce very uncertain results. This is contradictory to the options that India is developing in the context of limited war with Pakistan. If India attempts a limited confrontation and is not able to achieve desired results than it would be very difficult for Indians to avoid internal pressure of the military establishment and the masses to further increase the pressure that would ultimately escalate the situation into a full war and could therefore become a nuclear confrontation.

Comparison of the militaries are an important part of this analysis. India has without any question naval superiority but whether this naval superiority would be decisive enough is the real question. Long-term and short-term wars have different outcomes and in the context of nuclear confrontation, short-term conflicts are risky enough to escalate into full war. Therefore, in my opinion, naval superiority of India is much less likely to effect the outcome of a surgical strike or short-term war unlike 1965 or 1971. Kargil war 1999 is much more valid example in this context where in short-term conflict the navy had no such effect. Even if the scenario calls for a full or partial blockade, it takes time and is not of much worth in the context of short-term confrontation.

Again, in the case of air force, the air balance between India and Pakistan is also thought to heavily favor the larger and more technologically equipped Indian Air Force. However, gap between the air superiority between India and Pakistan has narrowed in the last decade. Modernization campaign Pakistan Air Force during the last decade has played a substantial 
role in narrowing this gap. Main reason is the lifting of U.S sanctions on military equipment supply to Pakistan in post $9 / 11$ period. This has significantly improved the preparedness of Pakistan Air Force. Modern aircrafts like JF-17 thunder, F-16 are key multi-role fighter jets with the capability to deliver nuclear tipped warheads. Adding to this inventory is the purchase of AWACS (new Airborne early Warning And Control Aircraft). Use of air force for surgical strikes is not easy. "Terrorist camps" that are to be attacked are not in open barren spaces rather they are allegedly located in the cities. This makes them a very difficult and next to impossible target for an air force because even if the target is destroyed by the conventional air to surface weapons, collateral damage would be so high that it would trigger a full scale war. Keeping in view the nuclear status of both countries, the scenario is likely to get out of hands if attempted. Not to mention the perception of Pakistan Air Force about this air aggression. There can be multiple scenarios.

\section{VI- Conclusion}

If we closely analyze geographical and political and security position of Pakistan and the history of India Pakistan military standoffs that could have been easily mishandled by either side to a full scale war that could have been nuclear consequences we see that there is a lack of restraint. Stating restraint is one thing and practicing restraint is another. Dynamics of limited war paradigm can lead to a full scale military conflict. Miscalculation on either side can have devastating consequences for the entire region. I have discussed in detail earlier the limitations of decision making time and other risky constraints that can trigger a nuclear confrontation. It should also be considered that subcontinent situation is much more different and complex than was between U.S and USSR during cold war. Diplomatic communication is the most sensitive area that had to be worked out between the two countries. If a genuine dialogue towards peace is, absent than war hysteria can mislead civil and military establishments of both sides. Accidental use of nuclear weapons from either side is another dimension of miscommunication and distrust between India and Pakistan. It is imperative that both India and Pakistan should remain in continuous contact to avoid any unfortunate miscalculation on either side. Peace can only prevail if it is given a chance.

\section{References}

Dr Samar Mubarakmand. "A Science Odyssey: Pakistan's Nuclear Emergence." Speech Delivered By Dr. Samar Mubarakmand. Lahore: Khawarzimic Society, November 30, 1998.

NTI (Nuclear Threat. NTI Profile." http://www.nti.org/e_research/profiles/Pakistan/Nuclear/print/5593_5594.prt (accessed May 11, 2008).

Ashuk Kapoor. Pakistan's Nuclear Development. New York: Croom Helm, 1987.

Shahid-ur-Rehman. Long Road to Chagai. Islamabad: Print wise Publication, 1999.

Haider K Nizamani. The Roots of Rhetoric; Politics of Nuclear Weapons in India and Pakistan. Westprot CT: Praeger, 2000.

Hooman Peimani. Nuclear Proliferation In The Indian Subcontinent . Westport CT: Praeger, 
2000.

Steven P Cohen. Pakistan Army: History and Organization. Karachi: Oxford University Press, 2002.

Owen Bennett Jones. Pakistan: Eye of The Storm. New Delhi: Penguin Books, 2002.

Lowell Dittmer. South Asia's Nuclear Security Dilemma; India, Pakistan amd China. New Delhi: Pentagon Press, 2005.

$\mathrm{H} \quad$ Khan. "Nuclear Control in Pakistan." www.pakdef.info. http://pakdef.info/nuclear\&missile/nuclearcontrol.html (accessed May 9, 2008).

Hilary Synnott. The Causes and Consequences of South Asia's Nuclear Tests. Karachi: Oxford University Press, 2001. 